\title{
I. SITE SURVEY ON THE MADAGASCAR RIDGE
}

\author{
Bhoopal Naini and John Chute, ${ }^{1}$ Lamont-Doherty Geological \\ Observatory, Columbia University, Palisades, New York
}

Deep Sea Drilling Project proposed Site 27 (24-5) on the Madagascar Ridge (not drilled) was surveyed by R/V Robert D. Conrad of Lamont-Doherty Geological Observatory during February 9-11, 1971. This site was proposed (as a possible location for drilling) based upon the findings of an earlier cruise of R/V Vema (cruise 24, Oct. 1, 1967) (Figure 1). The survey area is located over the southern part of the Madagascar Ridge. The bathymetric charts of Heezen and Tharp (1965) and Fisher (in press) show the Madagascar Ridge as a near-linear feature extending south of Madagascar trending south southwest until it connects the Southwest Indian Ocean ridge (SWIR). The Madagascar Ridge plunges down toward the south, and in the area of the site survey it rises about 2500 meters above the adjacent Mozambique Basin. There is no published account of the magnetic anomaly identification in this region. However, to the northeast of this site, in the Madagascar Basin magnetic anomalies extending to anomaly 25 of the Heirtzler et al. (1968 magnetic time scale have been identified by McKenzie and Sclater (1971). Deep Sea Drilling Project drilled a site (245, Leg 25) south of anomaly 25 in the Madagascar Basin and obtained an age of at least $63 \mathrm{~m} . \mathrm{y}$. for the basement (Simpson, Schlich, et al., 1972). The regional free-air gravity field as presented by Talwani and Kahle (in press) parallels the regional topographic trends of the ridge. There are isolated free-air gravity highs over the ridge, and the area of survey has one such high with a value of $73 \mathrm{mgal}$.

Bathymetric soundings (in corrected meters) in the survey area are contoured at 200-meter intervals (Figure 2 ). Total bathymetric relief over the survey region is of the order of 1400 meters. Overall, a northeast-southwest to north northeast-south southwest trend is observed.

\footnotetext{
'Also at Lehman College, The City University of New York, Bronx, N. Y.
}

A sediment isopach map for the region is given in Figure 3. Sediment thickness is contoured in tenths of seconds of two-way travel time $(0.1 \mathrm{sec}$ two-way travel time is approximately equal to $100 \mathrm{~m}$ sediment thickness assuming a mean velocity of $2 \mathrm{~km} / \mathrm{sec}$ ). The sediment is distributed as pockets in basement depressions, with a range in thickness between 0 and 700 meters and presents a northeast-southwest trend.

\section{ACKNOWLEDGMENT}

We thank Mr. Olav Eldholm for his comments on this report, Mr. John Ewing for the encouragement given in carrying out this work, and Dr. Eric Simpson of the University of Cape Town, South Africa, for his participation as a visiting scientist aboard R/V Conrad Cruise 14. Thanks are also due Miss Betty Batchelder for editorial help. This work was supported by Grants GA 27281 and GA 28338 from the National Science Foundation and the Office of Naval Research Contract N00014-67-A-0108-0004.

\section{REFERENCES}

Fisher, R. L., in press. Bathymetric charts of the Indian Ocean. In Udintsev, G. (Ed.), Geol. Geophys.

Heezen, B. C. and Tharp, M., 1965. Physiographic diagram of the Indian Ocean, the Red Sea, the South China Sea, the Sulu Sea and the Celebes Sea: New York (Geol. Soc. Am.) Heirtzler, J. R., Dickson, G. O., Herron, E. M., Pitman, W. C., and Le Pichon, X., 1968. Marine magnetic anomalies, geomagnetic field reversals, and motions of the ocean floor and continents: J. Geophys. Res., v. 73, p. 2119-2136.

McKenzie, D. and Sclater, J. G., 1971. The evolution of the Indian Ocean since the Late Cretaceous: Roy. Astron. Soc. Geophys. J., v. 25 , p. 437-528.

Simpson, E., Schlich, R., Leclaire, L., Moore, C., Girdley, W. A., White, S. M., Vallier, T., Muller, C., Zobel, B., Sigal, J., Gieskes, J., and Marshall, B. V., 1972. Leg 25 DSDP, Western Indian Ocean: Geotimes, v. 17, p. 21-24.

Talwani, M. and Kahle, H., in press. Free-air gravity maps in the Indian Ocean. In Udintsev, G. (Ed.), IIOE atlas geol. geophys. 


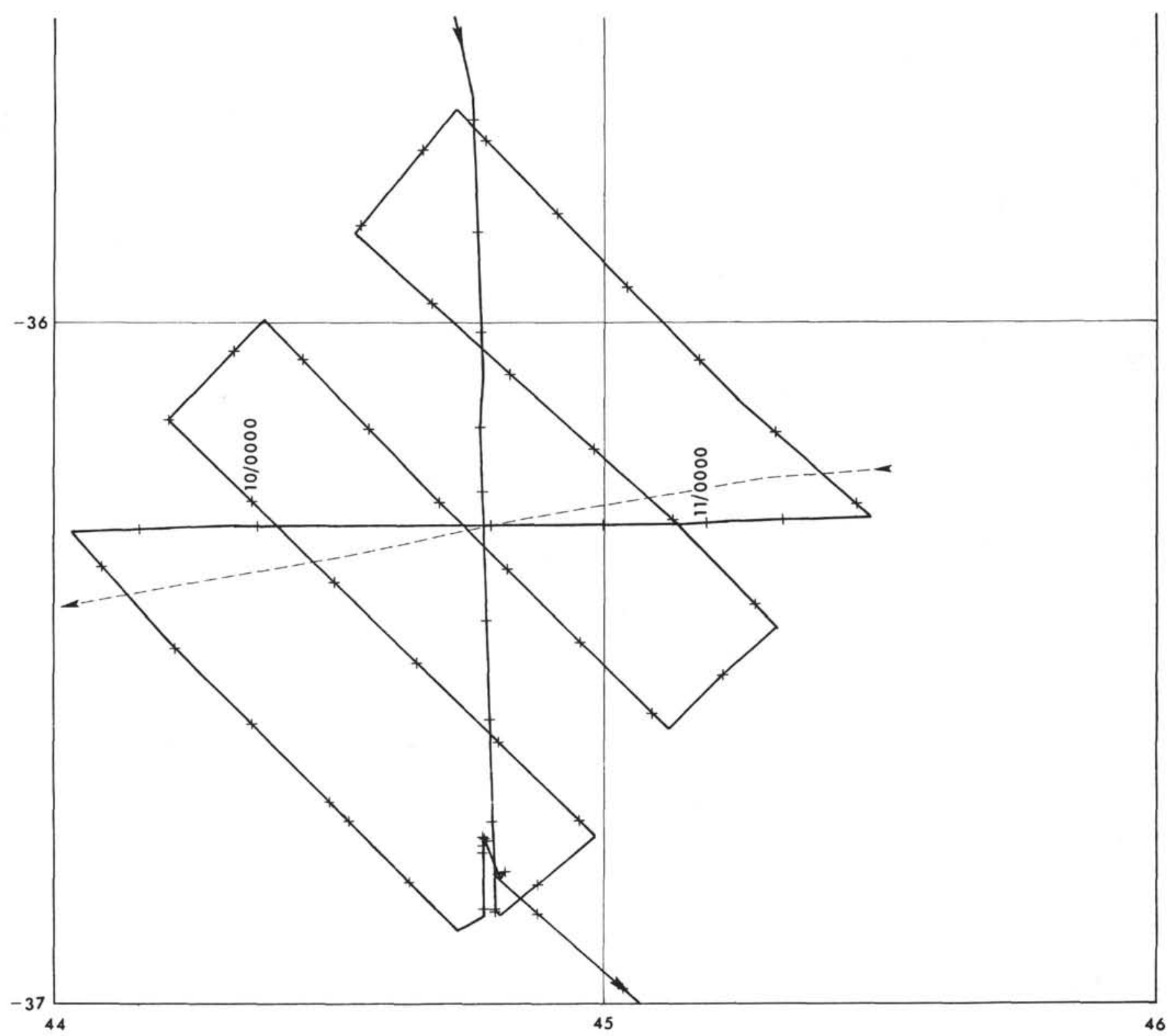

Figure 1. Area of survey with tracks of $R / V$ Conrad cruise 14 (solid line) with plus marks every hour on the hour. 0000 hours each day is identified with the date. Also shown is the track of $R / V$ Vema cruise 24 (dotted line). 


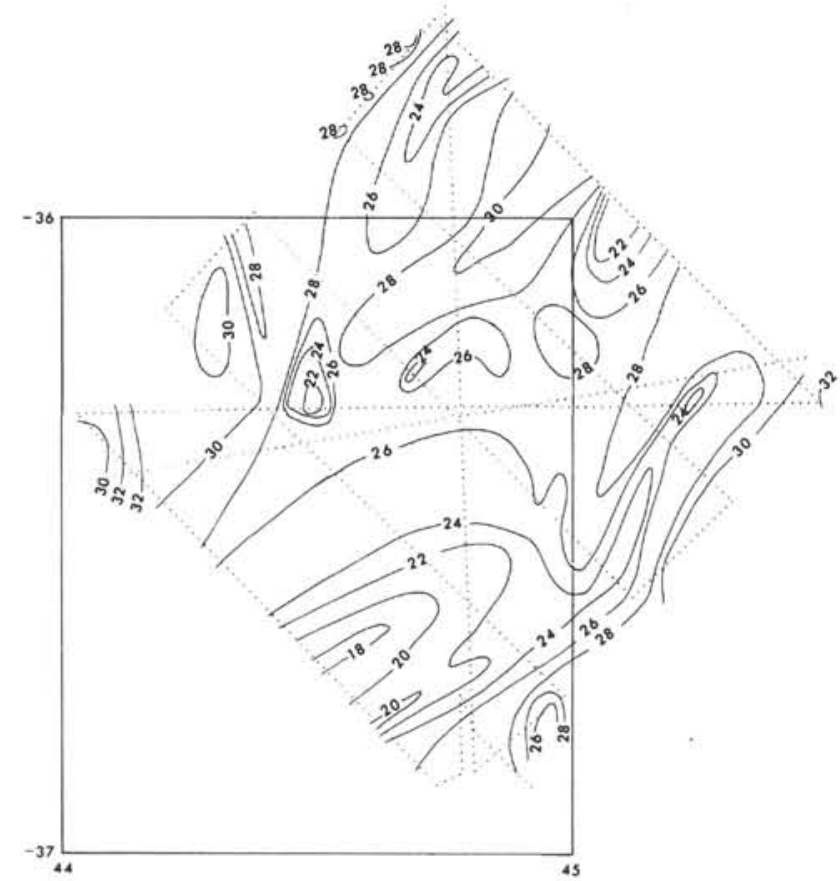

Figure 2. Bathymetric soundings in corrected meters. Contour interval 200 meters.

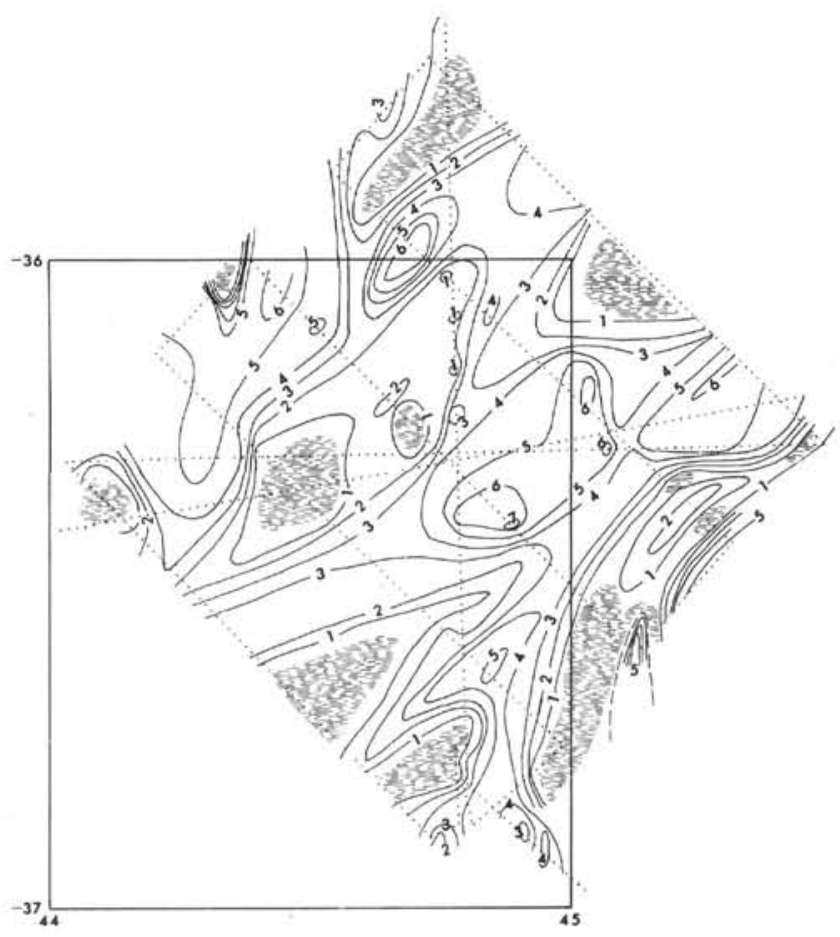

Figure 3. Sediment isopach map of the survey area. Contour interval tenth of a second (two-way travel time). Basement outcrops are shown by hachures. 